\title{
Relation between Methylenetetrahydrofolate Reductase C677T and A1298C Polymorphisms and Migraine Susceptibility
}

\author{
Vandana Rai, Pradeep Kumar \\ Department of Biotechnology, \\ VBS Purvanchal University \\ Jaunpur-222 003, UP, India.
}

\begin{abstract}
:
Migraine is a neurological disorder which impairs the patient's quality of life. Several association studies investigating the association between MTHFR gene C677T and A1298C polymorphisms and susceptibility to migraine were published. But the results were conflicting, so authors performed a meta-analysis of published case control studies. Four databases were searched for suitable studies up to December, 2018. Odds ratios (OR) with $95 \%$ confidence intervals (CI) was calculated adopting additive, homozygote, co-dominant, dominant, and recessive genetic models.

Results of MTHFR C677T polymorphism studies meta-analysis showed significant association with migraine risk using allele contrast, homozygote, dominant and recessive genetic models ( $\mathrm{T}$ vs. $\mathrm{C}$ : $\mathrm{OR}=1.18,95 \% \mathrm{CI}=1.00-1.26, \mathrm{p}=0.05$; $\mathrm{TT}$ vs. $\mathrm{CC}$ : $\mathrm{OR}=1.24$, $95 \% \mathrm{CI}=1.0-1.5, \mathrm{p}=0.04 ; \mathrm{CT}$ vs. $\mathrm{CC}: \mathrm{OR}=1.08,95 \% \mathrm{CI}=0.97-1.07, \mathrm{p}=0.25 ; \mathrm{TT}+\mathrm{CT}$ vs. $\mathrm{CC}: \mathrm{OR}=1.15,95 \% \mathrm{CI}=1.0-1.29, \mathrm{p}=0.04$; $\mathrm{TT}$ vs. $\mathrm{CT}+\mathrm{CC}: \mathrm{OR}=1.97,95 \% \mathrm{CI}=$ 1.28-3.42, $\mathrm{p}=0.002$ ). However, results of MTHFR A1298 polymorphism studies metaanalysis did not show any association with migraine. Subgroup analysis based on ethnicity and migraine types i. e migraine with aura (MA) and without aura (MO) were also performed. Results of present meta-analysis indicate overall association between MTHFR C677T polymorphism with migraine in total 24 studies, in Asian population and in MA cases but did not show any association with Caucasian population and MO cases .
\end{abstract}

Keywords:

Migraine, MTHFR, C677T, A1298C, polymorphism, homocysteine, risk factors

\section{Introduction:}

Migraine is a highly prevalent neurological disorder affecting up to $20 \%$ of the general population [1]. It is characterized by recurrent episodes of headache, nausea, vomiting, photophobia, phonophobia and autonomic nervous system dysfunction [2]. International Headache Society (IHS) defined two major classes of migraine: migraine with aura (MA) and migraine without aura (MO).

Migraine is considered a polygenic multifactorial disease with several genes participating in its pathogenesis through interaction with environmental factors [3,4]. About $50 \%$ of affected individuals have a first-degree relative also suffering from migraine [5-7]. Family and twin studies support the idea of MO and MA being different phenotypes of the same entity, with a heritability ranging from 33 to $57 \%[6,8,9]$. The number and types of genes responsible for migraine are still not clearly known. 
Among all the genes associated with common migraine and MA, the 5,10methylenetetrahydrofolate reductase (MTHFR) gene is the most thoroughly studied one. MTHFR gene is located on chromosome 1 (1p36.3) and contains 11 exons. Several polymorphisms are reported in MTHFR gene, but C677T and A1298C polymorphisms are clinically very important and most studied so far. In C677T polymorphism, cytosine at 677 position is substituted by thymine. This substitution makes MTHFR enzyme thermolabile with reduced enzymatic activity. $\mathrm{T}$ allele frequency varied worldwide and well studied in several populations [10-13]. A1298C polymorphism involving alanine to cytosine substitution in MTHFR gene has also been reported to reduce enzyme activity [14]. The prevalence of the A1298C homozygote variant (CC) ranges from 7 to $12 \%$ in White populations of North America and Europe. Lower frequencies have been reported in Hispanics (4 to $5 \%$ ), and Asian populations (1 to 4\%) [15,16]. (The enzyme 5,10methylenetetrahydrofolate reductase (MTHFR) is an important enzyme in the homocysteine metabolism and catalyzes the conversion of 5,10methylenetetrahydrofolate into 5-methyltetrahydrofolate, the predominant circulating form of folate. Normal MTHFR activity is crucial to maintain the pool of circulating folate and methionine and to prevent the accumulation of homocysteine $[17,18]$. The $677 \mathrm{~T}$ allele is associated with reduced enzyme activity, and mildly increased plasma total homocysteine (tHcy) concentrations [17,18]. MTHFR gene polymorphisms have been reported as risk factor for several neurological and psychiatric diseases/ disorders likeNeural tube defects [19], Down syndrome [20], Alzheimer's disease [21], Parkinsons' disease [22], schizophrenia [23], autism [24] and epilepsy [25] etc.

Several case control association studies investigating MTHFR C677T and A1298C polymorphisms role in migraine susceptibility were published but results were contradictory. Some studies reported positive association [26,27] and some other studies showed negative association [28,29]. To clarify the association between C677T and A1298C polymorphisms and migraine risk, present meta-analysis was performed by including more recent publications to improve the efficiency of meta-analysis.

\section{Methods:}

Meta-analysis was carried out according to MOOSE guidelines [30].

\section{Selection of studies:}

All studies that investigated the association of the MTHFR C677T polymorphism with migraine, published before December, 2018 were considered in the present metaanalysis. These studies were identified by extended computer based search of the PubMed (http://www.ncbi.nlm.nih.gov/pubmed), Google Scholar (http://scholar.google.com), Science Direct (http://www.sciencedirect.com), and Springer Link (http://link.springer.com) databases. The combination of the following terms was used as a search criterion: "MTHFR', C677T', "A1298C"," "methylenetetrahydrofolate reductase", "migraine". All references cited in the retrieved studies were also reviewed to identify additional articles not indexed in these databases.

\section{Data extraction:}

The following information about the eligible studies was extracted: first author name, year of publication, country of study, ethnicity of studied subjects, full genotyping data for the case and control groups. The frequencies of the alleles were calculated, for the cases and the controls, from the corresponding genotype distributions. 


\section{Inclusion and exclusion criteria:}

The inclusion criteria for the present meta-analysis are following: (i) Studies must have case-control or cohort design. (ii) Authors must investigated patients with migraine and healthy control subjects. (iii) Authors must provided information on genotype numbers/frequencies or sufficient data to calculate these. (iv) Studies must be published as full articles.

Studies were excluded if: 1) they were case reports, editorials review, letter to editors and book chapters (2) incomplete raw data/information and not providing complete information for number of genotype and/or allele number calculation, 3) studies based on pedigree, and genome scans, since they investigate linkage.

\section{Statistical analysis:}

The meta-analysis examined the overall association of $\mathrm{T}$ (C677T polymorphism) and $\mathrm{C}$ (A1298C polymorphism) alleles and risk of migraine compared with $\mathrm{T}$ and $\mathrm{A}$ alleles respectively, using the allele contrast/additive model, homozygote model, codominant/heterozygote model, recessive model and dominant model. The effect of association was indicated as odds ratio (OR) with the corresponding 95\% confidence interval (CI). The pooled OR was estimated using fixed effects (FE) [31] and random effects (RE) model [32]. RE modeling assumes heterogeneity between the studies, and it incorporates the between-study variability. The heterogeneity between studies was tested by the $Q$ statistic [33]. If $\mathrm{p}<0.05$ then the heterogeneity was considered statistically significant. Heterogeneity was quantified by the $\mathrm{I}^{2}$ metric $\left(\mathrm{I}^{2}<25 \%\right.$ no heterogeneity; $\mathrm{I}^{2}=25-50 \%$ moderate heterogeneity; $\mathrm{I}^{2}>50 \%$ large or extreme heterogeneity) [34] . The distribution of the genotypes in the control group was tested for Hardy-Weinberg equilibrium using calculator available at http://ihg.gsf.de/cgi-bin/hw/hwa1.pl. Studies with the controls not in Hardy-Weinberg equilibrium (HWE) were subjected to a sensitivity analysis [35], i.e., the effect of excluding specific studies was examined. Subgroup analysis based on ethnicity was also performed .

Publication bias was tested by funnel plot asymmetry using Egger's linear regression test. The significance of the intercept was determined by the t-test considering p-value $<0.05$ as representation of statistically significant publication bias [36]. All analyses were performed using the computer programs MetaAnalyst [37] and MIX version 1.7 [38]. A p value less than 0.05 was considered statistically significant, and all the $p$ values were two sided.

\section{Results:}

\section{Eligible studies:}

A diagram schematizing the study selection process is presented in Figure 1. Initial PubMed, Google Scholar, Science Direct and Elsevier Link databases search, total 126 studies were retrieved. After title and abstract evaluation, 83 articles were eliminate, which were irrelevant for the present meta-analysis. These 83 publications were reviews, case studies, editorials, comments, reviews, meta-analysis etc. Following inclusion and exclusion criteria, total 24 case-control studies were found suitable for the meta-analysis [26-29,39-58] (Table 1). Out of 24 studies, only in three studies A1298C polymorphism was investigated (Table 2).

These studies were reported from different countries like- Australia [41], Austria [56], Spain [42], Netherlands [44], Germany [45], Finland [28], Iceland [52], India [50,57], 
Iran [58], Italy [43,46,47], Portugal [49], Canada [53], Japan [29,39], China [54], Russia [26], Spain [51], Turkey [27,40], and USA [48,55] (Table 1).

\section{Summary statistics:}

In MTHFR C677T polymorphism studies, number of cases and controls were 10,644 and 30,143 respectively. Except two studies [40,56], distribution of the C677T genotype in the control group of all 22 studies was in Hardy-Weinberg equilibrium $(\mathrm{p}<0.05)$, indicating a lack of genotyping, sampling errors and/or population stratification [59] (Table 1). Odds ratio in ten studies was below one and did not reported association[28,29,42,43,45,48,49,51,52,55], and other fourteen studies reported association between MTHFR C677T polymorphism and migraine. In cases, the frequency of CC, CT and TT genotypes were $45.0 \%, 44.1 \%$ and $11 \%$ respectively. In control groups, the frequencies of CC, CT and TT-homozygous individuals were $45.35 \%$, $43.57 \%$, and $11.07 \%$, respectively.

In MTHFR A1298C polymorphism studies, number of cases and controls were 348 and 488 respectively. Except Kara et al.[40], distribution of the A1298C genotype in the control group of all 2 studies was in Hardy-Weinberg equilibrium $(\mathrm{p}<0.05)$. In cases, the frequency of $\mathrm{AA}, \mathrm{AC}$ and $\mathrm{CC}$ genotypes were $37.93 \%, 45.11 \%$ and $16.95 \%$ respectively. In control groups, the frequencies of $\mathrm{AA}, \mathrm{AC}$ and $\mathrm{CC}$ genotypes were 39.95 $\%, 46.31 \%$ and $13.72 \%$ respectively.

\section{MTHFR C677T meta-analysis:}

Meta-analysis of 24 studies for investigating the association of the MTHFR C677T polymorphism, showed higher heterogeneity using all five genetic models $\left(\mathrm{p}<0.0001, \mathrm{I}^{2}=\right.$ $87.57 \%$ ); so random effect model was adopted. The random effects pooled OR was not statistically significant ( $\mathrm{T}$ vs $\mathrm{C}: \mathrm{OR}=1.18 ; 95 \% \mathrm{CI}=1.00-1.26 ; \mathrm{p}=0.05$; $\mathrm{CT}$ vs $\mathrm{CC}$ : $\mathrm{OR}=$ $1.08 ; 95 \% \mathrm{CI}=0.97-1.07 ; \mathrm{p}=0.25 ; \mathrm{TT}$ vs $\mathrm{CC}: \mathrm{OR}=1.24 ; 95 \% \mathrm{CI}=1.0-1.51 ; \mathrm{p}=0.04$; $\mathrm{TT}+\mathrm{CT}$ vs $\mathrm{CC}: \mathrm{OR}=1.15 ; 95 \% \mathrm{CI}=1.0-1.29 ; \mathrm{p}=0.04 ; \mathrm{TT}$ vs $\mathrm{CT}+\mathrm{CC}: \mathrm{OR}=1.97 ; 95 \%$ $\mathrm{CI}=1.28-3.42 ; \mathrm{p}=0.002$ ) (Table 3; Figure 2).

\section{MTHFR A1298C meta-analysis:}

Meta-analysis of three A1298C studies showed that MTHFR A1298C polymorphism was not associated with migraine $(\mathrm{C}$ vs $\mathrm{A}$ : $\mathrm{OR}=1.18,95 \% \mathrm{CI}=0.96-1.44, \mathrm{p}=0.11$; $\mathrm{AC}$ vs $\mathrm{AA}: \mathrm{OR}=1.03,95 \% \mathrm{CI}=0.76-1.39, \mathrm{p}=0.84$; $\mathrm{CC}$ vs $\mathrm{AA}: \mathrm{OR}=1.55,95 \% \mathrm{CI}=1.0-2.4$, $\mathrm{p}=0.05 ; \mathrm{CC}+\mathrm{AC}$ vs $\mathrm{AA}: \mathrm{OR}=1.13,95 \% \mathrm{CI}=0.85-1.51, \mathrm{p}=0.39 ; \mathrm{CC}$ vs $\mathrm{AC}+\mathrm{AA}: \mathrm{OR}=$ $1.47,95 \% \mathrm{CI}=0.98-2.19, \mathrm{p}=0.05$ ) (Table 4, Figure 3).

\section{Subgroup analysis:}

Subgroup analysis were performed on the bases of ethnicity and type of migraine i. e MA and MO. In total 24 studies, Asian and Caucasian subjects were genotyped in eight and sixteen studies respectively. Sixteen Caucasian studies meta-analysis included 9,689 cases and 28,858 controls did not show association between C677T and migraine risk ( $\mathrm{T}$ vs $\mathrm{C}: \mathrm{OR}=0.97 ; 95 \% \mathrm{CI}=0.93-1.01 ; \mathrm{p}=0.19$; $\mathrm{TT}$ vs $\mathrm{CC}: \mathrm{OR}=0.99 ; 95 \% \mathrm{CI}=0.86-1.15$; $\mathrm{p}=0.95$ ) (Table 3, Figure 4). Meta-analysis of 8 Asian studies (955 cases and 1,285 controls) showed strong significant association ( $\mathrm{T}$ vs $\mathrm{C}$ : $\mathrm{OR}=1.91 ; 95 \% \mathrm{CI}=1.06-3.45$; $\mathrm{p}=0.03$; TT vs. $\mathrm{CC}: \mathrm{OR}=2.98 ; 95 \% \mathrm{CI}=1.56-5.68 ; \mathrm{p}=0.008$ ) between C677T polymorphism and migraine risk (Table 3 , Figure 5).

Out of total 24 studies, 19 studies included 3,177 MA cases and 7,921 controls. Allele contrast meta-analysis of MA studies showed significant association between C677T 
polymorphism and MA (T vs $\mathrm{C}: \mathrm{OR}=1.26 ; 95 \% \mathrm{CI}=1.03-1.54 ; \mathrm{p}=0.02$; $\mathrm{TT}$ vs $\mathrm{CC}: \mathrm{OR}=$ $1.51 ; 95 \% \mathrm{CI}=1.05-2.17 ; \mathrm{p}=0.02$ ) (Table 3, Figure 6). Higher significant heterogeneity was observed but publication bias was not observed in meta-analysis of MA studies. Meta-analysis of seventeen MO studies with 2347 cases and 6406 controls, did not show association between $\mathrm{C} 677 \mathrm{~T}$ polymorphism and $\mathrm{MO}(\mathrm{OR}=1.07 ; 95 \% \mathrm{CI}=0.84-1.36 ; \mathrm{p}=$ 0.56) (Table 3, Figure 6).

\section{Publication bias:}

In total MTHFR C677T studies meta-analysis, except recessive model publication bias was not observed in other four models (Egger's $p=0.09$ for T vs. C; Egger's $p=0.06$ for TT vs. CC; Egger's p $=0.39$ for CT vs. CC; Egger's $\mathrm{p}=0.12$ for TT $+\mathrm{CC}$ vs. CT; Egger's TT vs. CT+CC $<0.0001$ ) of overall meta-analysis (Table 3,Figure 8). In A1298C studies, publication bias was absent (Table 4).

\section{Discussion:}

Present meta-analysis was based on data from 24 case-control studies with 10,644 migraine cases and 30,143 controls. Results showed significant association between C677T polymorphism and migraine risk in total 24 studies, Asian populations and MA cases. A1298C polymorphism meta-analysis did not show any association with migraine risk.

Although patho-physiology of migraine is not very well known, but it is considered as disorder of brain with endothelial dysfunction [60] and altered vascular reactivity [61]. TT genotype and/or T allele may lead moderate hyperhomocyeteinemia [40,41] and it is well established fact that higher concentration of homocysteine is toxic to neurons and causes DNA stand breaks, and altered DNA repair, DNA methylation and oxidative stress $[62,63,64,65]$. Hyperhomocysteinemia produce endothelial cell injury, which may activate trigeminovascular system (TVS), resulting in an inflammatory action in the meninges and dilation of the large cerebral vessels. These changes may start the progression of migraine $[40,41,66]$. The characteristic head pain in migraine may arise due to dilation of cerebral blood vessels following activation of the TVS [41].

Meta-analysis is a useful strategy for elucidating genetic factors in different diseases/disorders. Several meta-analysis were published which evaluated risk of folate pathway genes polymorphism for different disease and disorders- like Down syndrome [67,68], glucose 6-phosphate dehydrogenase deficiency [69], cleft lip/palate [70], neural tube defects [71], recurrent pregnancy loss [72], endometrial cancer [73], male infertility [74], depression [75], schizophrenia [76,77], epilepsy [78], autism [79], Alzheimer's disease [80], prostate cancer [81], breast cancer [82,83], colorectal cancer [84], Esophageal cancer [85], and digestive tract cancer [86] etc.

Four meta-analyses were published so far in order to draw a reliable conclusion regarding association between $\mathrm{C} 677 \mathrm{~T}$ polymorphism and migraine susceptibility [52,53,87,88]. Rubino et al. [87] conducted a meta-analysis associating the C677T polymorphism with migraine based on nine published articles (2961 migraineurs, 2170 with MA and 791 with MO), providing evidence for an association of the MTHFR gene only in MA (FE: $\mathrm{OR}=1.30,95 \% \mathrm{CI}=1.06-1.58$; $\mathrm{RE}$ : $\mathrm{OR}=1.66,95 \% \mathrm{CI}=1.06-2.59$ ). Similar observation that the MTHFR 677TT genotype is associated with an increased risk for MA among non-Caucasian population ( $\mathrm{OR}=1.48,95 \% \mathrm{CI}=1.02-2.13)$ was supported by the meta-analysis of 13 studies by Schurks and co-workers [52]. On the contrary, Samaan et al. [53] including five datasets of Caucasians demonstrated that the 
TT genotype was associated with total migraine in non-Caucasian population, whereas for Caucasians, this variant was associated with MA only (OR 1.31, 95\% CI 1.01-1.70, p $=0.039)$. A meta-analysis of 16 case-control studies showed that $\mathrm{T}$ allele homozygosity is significantly associated with $\mathrm{MA}(\mathrm{OR}=1.42 ; 95 \% \mathrm{CI}, 1.10-1.82)$ and total migraine $(\mathrm{OR}=1.37 ; 95 \% \mathrm{CI}, 1.07-1.76)$, but not migraine without aura $(\mathrm{OR}=1.16 ; 95 \% \mathrm{CI}$, 0.36-3.76) [88]. In present meta-analysis largest number of studies and largest number of samples $(40,787)$ were included.

Similar to other meta-analysis, present meta-analysis have also few limitations, which should be acknowledged like- (i) the pooled OR was based on unadjusted individual ORs, (ii) higher between studies heterogeneity was present, although author tried to eliminate that by performing subgroup analysis, (iii) publication bias was present, which denoted that the some studies with negative results were not included in the present metaanalysis, (iv) owing to lack of information, gene-gene and gene environment interactions could not be carried out in present meta-analysis. Along with limitations, present metaanalysis had several strengths also like (i) highest number of studies and samples were included (ii) controls were healthy and were matched to cases and (iii) subgroup analysis was performed.

In conclusion, the results of present meta-analysis showed significant association between migraine risk with MTHFR C677T polymorphism $(\mathrm{OR}=1.24)$ but did not show any association with MTHFR A1298C polymorphism. In ethnicity based subgroup analysis, positive significant association was found between C677T polymorphism and Asian migraine cases $(\mathrm{OR}=2.98)$ but not with Caucasian cases $(\mathrm{OR}=0.99)$. Further migraine subgroup meta-analysis showed association between C677T polymorphism and migraineurs with aura $(\mathrm{OR}=1.51)$ but not with migraineurs without aura.

Conflict of interest: Authors declared no conflict of interest.

Ethical Approval : Present manuscript is a meta-analysis/review, hence, ethical clearance is not required for the present manuscript, no human blood/ tissue samples are used in the present manuscript.

\section{References:}

1. Haut SR, Bigal ME, Lipton RB (2006) Chronic disorders with episodic manifestations: focus on epilepsy and migraine. Lancet Neurol 5: 148-157.

2. Headache Classification Subcommittee of the International Headache Society (2004) The International Classification of Headache Disorders: 2nd edition. Cephalalgia 24(Suppl 1): 9-160.

3. Montagna P (2000) Molecular genetics of migraine headaches: a review. Cephalalgia 20(1): 3-14.

4. Wessman M, Terwindt GM, Kaunisto MA, Palotie A, Ophoff RA (2007) Migraine: a complex genetic disorder. Lancet Neurol 6(6): 521-32.

5. Bille B (1997) A 40-year follow-up of school children with migraine. Cephalalgia 17(4): 488-491.

6. Mulder EJ, van Baal C, Gaist D, Kallela M, Kaprio J, Svensson DA, Nyholt DR, Martin NG, MacGregor AJ, Cherkas LF, Boomsma DI, Palotie A (2003) Genetic and environmental influences on migraine: a twin study across six countries. Twin Res 6(5): 422-431. 
7. Svensson DA, Larsson B, Waldenlind E, Pedersen NL (2003) Shared rearing environment in migraine: results from twins reared apart and twins reared together. Headache 43(3): 235- 244.

8. Nyholt DR, Gillespie NG, Heath AC, Merikangas KR, Duffy DL, Martin NG (2004) Latent class and genetic analysis does not support migraine with aura and migraine without aura as separate entities. Genet Epidemiol 26(3):231-244.

9. Ligthart L, Boomsma DI, Martin NG, Stubbe JH, Nyholt DR (2006) Migraine with aura and migraine without aura are not distinct entities: further evidence from a large Dutch population study. Twin Res Hum Genet 9(1):54-63.

10. Wilcken B, Bamforth F, Li Z, Zhu H, Ritvanen A, Renlund M, et al. (2003) Geographical and ethnic variation of the $677 \mathrm{C}>\mathrm{T}$ allele of 5,10 methylenetetrahydrofolate reductase (MTHFR): Findings from over 7000 newborns from 16 areas worldwide. J Med Genet 40: 619-625.

11. Rai V, Yadav U, Kumar P, Yadav SK (2010) Methyleletetrahydrofolate reductase polymorphism (C677T) in Muslim population of Eastern Uttar Pradesh, India. Ind J Med Sci 64(5): 219-223.

12. Rai V, Yadav U, Kumar P (2012) Genotype prevalence and allele frequencies of 5,10-methylenetetrahydrofolate reductase (MTHFR) C677T mutation in two caste groups of India. Cell Mol Biol 58: OL1695- 701.

13. Yadav U, Kumar P, Gupta S, Rai V (2017) Distribution of MTHFR C677T gene polymorphism in healthy North Indian population and an updated meta-analysis. Ind J Clin Biochem 32(4):399-410.

14. Weisberg P, Tran B, Christensen S, Sibani S, Rozen R (1998) A second genetic polymorphism in methylenetetrahydrofolate reductase (MTHFR) associated with decreased enzyme activity. Mol Genet Metab 64:169-172.

15. Botto LD, Yang Q (2000) 5,10-Methylenetetrahydrofolate reductase gene variants and congenital anomalies: a HuGE review. Am J Epidemiol 151: 862-877.

16. Robien K, Ulrich CM (2003) 5,10- Methylenetetrahydrofolate reductase polymorphisms and leukemia risk: a HuGE mini-review. Am J Epidemiol 157: 571-582.

17. Frosst P, Blom HJ, Milos R, Goyette P, Sheppard CA, Matthews RG, Boers GJ, den Heijer M, Kluijtmans LA, van den Heuvel LP, et al. (1995) A candidate genetic risk factor for vascular disease: a common mutation in methylenetetrahydrofolate reductase. Nat Genet 10:111-113.

18. Jacques PF, Bostom AG, Williams RR, Ellison RC, Eckfeldt JH, Rosenberg IH, et al. (1996) Relation between folate status, a common mutation in methylenetetrahydrofolate reductase, and plasma homocysteine concentrations. Circulation 93: 7-9.

19. Liu ZZ, Zhang JT, Liu D, Hao YH, Chang BM, Xie J, Li PZ (2013) Interaction between maternal 5, 10-methylenetetrahydrofolate reductase C677T and methionine synthase A2756G gene variants to increase the risk of fetal neural tube defects in a Shanxi Han population. Chin Med J (Engl) 126(5): 865-869.

20. Elsayed GM, Elsayed SM, Ezz-Elarab SS (2013) Maternal MTHFR C677T genotype and septal defects in offspring with Down syndrome: A pilot study. The Egyptian J Med Hum Genet 15(1): 39-44. 
21. Mansouri L, Fekih-Mrissa N, Klai S, Mansour M, Gritli N, Mrissa R (2013) Association of methylenetetrahydrofolate reductase polymorphisms with susceptibility to Alzheimer's disease, Clin Neurol Neurosurg 115: 1693-1696.

22. Białecka M, Kurzawski M, Roszmann A, Robowski P, Sitek EJ, Honczarenko K, et al. (2012) Association of COMT, MTHFR, and SLC19A1(RFC-1) polymorphisms with homocysteine blood levels and cognitive impairment in Parkinson's disease. Pharmacogenet. Genomics 22: 716-724.

23. Nishi, A., Numata, S., Tajima, A., Kinoshita, A., Kikuchi, K., Shimodera, S. et al. (2014) Meta-analyses of blood homocysteine levels for gender and genetic association studies of the MTHFR C677T polymorphism in schizophrenia. Schizophr Bull 40(5): 1154-1163.

24. Shawky RM, El-baz F, T Kamal TM, Elhossiny RM, Ahmed MA, El Nady GH (2014) Study of genotype-phenotype correlation of methylene tetrahydrofolate reductase (MTHFR) gene polymorphisms in a sample of Egyptian autistic children. The Egyptian Journal of Medical Human Genetics 15: 335-341.

25. Prasad AN, Rupar CA, Prasad C (2011) Methylenetetrahydrofolate reductase (MTHFR) deficiency and infantile epilepsy. Brain Dev 33:758-69.

26. Azimova JE, Sergeev AV, Korobeynikova LA, Kondratieva1 NS, Kokaeva ZG, Shaikhaev GO, Skorobogatykh KV, Fokina NM, Tabeeva GR, Klimov EA (2013) Effects of MTHFR gene polymorphism on the clinical and electrophysiological characteristics of migraine. BMC Neurology 13:103-109.

27. Bahadir A, Eroz R, Dikici S (2013) Investigation of MTHFR C677T gene polymorphism, biochemical and clinical parameters in Turkish migraine patients: association with allodynia and fatigue. Cell Mol Neurobiol 33:1055-1063.

28. Kaunisto M, Kallela M, Hamalainen E, Kilpikari R, Havanka H, Harno H, Nissila M, Sako E, Ilmavirta M, Liukkonen J, Teirmaa H, Tornwall O, Jussila M,Terwilliger J, Farkkila M, Kaprio J, Palotie A, Wessman M (2006) Testing of variants of the MTHFR and ESR1 genes in 1798 Finnish individuals fails to confirm the association with migraine with aura. Cephalalgia 26(12):1462-1472.

29. Ishii M, Shimizu S, Sakairi Y, Nagamine A, Naito Y, Hosaka Y, Naito Y, Kurihara T, Onaya T, Oyamada H, Imagawa A, Shida K, Takahashi J, Oguchi K, Masuda Y, Hara H, Usami S, Kiuchi Y (2012) MAOA, MTHFR, and TNFbeta genes polymorphisms and personality traits in the pathogenesis of migraine. Mol Cell Biochem 363(1-2): 357-66.

30. Stroup DF, Berlin JA, Morton SC, Olkin I, Williamson GD, Rennie D, et al. (2000) Meta-analysis of observational studies in epidemiology: a proposal for reporting. Meta-analysis Of Observational Studies in Epidemiology (MOOSE) group. JAMA 283(15) 2008-2012.

31. Mantel N, and Haenszel W (1959): Statistical aspects of the analysis of data from retrospective studies of disease. J Natl Cancer Inst 22(4): 719-48.

32. DerSimonian R, Laird N (1986) Meta-analysis in clinical trials. Controlled Clin Trials 7: 177-188.

33. Zintzaras E, Ioannidis JP (2005) HEGESMA: genome search meta-analysis and heterogeneity testing. Bioinformatics 21(18): 3672-3.

34. Higgins JP, Thompson SG (2002) Quantifying heterogeneity in a meta-analysis. Stat Med 21: 1539-1558. 
35. Zintzaras E (2006) C677T and A1298C methylenetetrahydrofolate reductase gene polymorphisms in schizophrenia, bipolar disorder and depression: a meta-analysis of genetic association studies. Psychiatr Genet 16(3):105-115.

36. Egger M, Davey Smith G, Schneider M, Minder C (1997) Bias in meta-analysis detected by a simple, graphical test. BMJ 315: 629-34.

37. Wallace BC, Dahabreh IJ, Trikalinos TA, Lau J, Trow P, Schmid CH (2013) Closing the gap between methodologists and end-users: $\mathrm{R}$ as a computational back-end. J Stat Softw 49: 1-15.

38. Bax L, Yu LM, Ikeda N, Tsuruta H, Moons KG (2006) Development and validation of MIX: comprehensive free software for meta-analysis of causal research data. BMC Med Res Methodol 6:50-58.

39. Kowa H, Yasui K, Takeshima T, Urakami K, Sakai F, Nakashima K (2000) The homozygous C677T mutation in the methylenetetrahydrofolate reductase gene is a genetic risk factor for migraine. American Journal of Medical Genetics 96(6):762-764.

40. Kara I, Sazci A, Ergul E, Kaya G, Kilic G (2003) Association of the C677T and A1298C polymorphisms in the 5,10 methylenetetrahydrofolate reductase gene in patients with migraine risk. Brain Research Molecular Brain Research 111(12):84-90.

41. Lea R, Ovcaric M, Sundholm J, MacMillan J, Griffiths L (2004) The methylenetetrahydrofolate reductase gene variant C677T influences susceptibility to migraine with aura. BMC Medicine 2(1):3.

42. Oterino A, Valle N, Bravo Y, Munoz P, Sanchez-Velasco P, Ruiz-Alegria C,Castillo J, Leyva-Cobian F, Vadillo A, Pascual J (2004) MTHFR T677 homozygosis influences the presence of aura in migraineurs. Cephalalgia 24(6):491-494.

43. Oterino A, Valle N, Pascual J, Bravo Y, Munoz P, Castillo J, Ruiz-Alegria C, Sanchez-Velasco P, Leyva-Cobian F, Cid C (2005) Thymidylate synthase promoter tandem repeat and MTHFD1 R653Q polymorphisms modulate the risk for migraine conferred by the MTHFR T677 allele. Molecular Brain Research 139(1):163-168.

44. Scher AI, Terwindt GM, Verschuren WMM, Kruit MC, Blom HJ, Kowa H, Frants RR, van den Maagdenberg AMJM, van Buchem M, Ferrari MD,Launer LJ (2006) Migraine and MTHFR C677T genotype in a population-based sample. Annals of Neurology 59(2): 372-375.

45. Todt U, Freudenberg J, Goebel I, Netzer C, Heinze A, Heinze-Kuhn K, Göbel H, Kubisch C (2006) MTHFR C677T polymorphism and migraine with aura. Annals of Neurology 60(5):621-622.

46. Bottini F, Celle M, Calevo M, Amato S, Minniti G, Montaldi L, Pasquale DD, Cerone R, Veneselli E, Molinari A (2006) Metabolic and genetic risk factors for migraine in children. Cephalalgia 26(6):731-737.

47. Pezzini A, Grassi M, Del Zotto E, Giossi A, Monastero R, Dalla Volta G, Archetti S, Zavarise P, Camarda C, Gasparotti R, Magoni M, Camarda R, Padovani A (2007) Migraine mediates the influence of C677T MTHFR genotypes on ischemic stroke risk with a stroke-subtype effect. Stroke 38(12): 3145-51. 
48. Schurks M, Zee RYL, Buring JE, Kurth T (2008) Interrelationships among the MTHFR 677C > T polymorphism, migraine, and cardiovascular disease. Neurology 71(7): 505-513.

49. Ferro A, Castro MJ, Lemos C, Santos M, Sousa A, Pereira-Monteiro J, Sequeiros J, Maciel P (2008) The C677T polymorphism in MTHFR is not associated with migraine in Portugal. Disease Markers 25(2): 107-113.

50. Joshi G, Pradhan S, Mittal B (2009) Role of the ACE ID and MTHFR C677T polymorphisms in genetic susceptibility of migraine in a north Indian population. Journal of the Neurological Sciences 277(1-2):133-137.

51. Oterino A, Toriello M, Valle N, Castillo J, Alonso-Arranz A, Bravo Y, RuizAlegria C, Quintela E, Pascual J (2010) The relationship between homocysteine and genes of folate-related enzymes in migraine patients. Headache 50(1): 99168.

52. Schurks M, Rist PM, Kurth T (2010) MTHFR 677C>T and ACE D/I polymorphisms in migraine: a systematic review and meta-Analysis. Headache. 2010 Apr; 50(4): 588-599.

53. Samaan Z, Gaysina D, Cohen-Woods S, Craddock N, Jones L, Korszun A, Owen M, Mente A, McGuffin P, Farme A (2011) Methylenetetrahydrofolate reductase gene variant (MTHFR C677T) and migraine: a case control study and meta-analysis. BMC Neurol 11: 66.

54. An XK, Lu CX, Ma QL, Zhang XR, Burgunder JM, Lin Q, Qu HL (2013) Association of MTHFR C677T polymorphism with susceptibility to migraine in the Chinese population. Neurosci Lett 549:78-81.

55. Scher AI, Eiriksdottir G, GarciaM, Feit P, Smith AV, Harris TB, et al. (2013) Lack of association between the MTHFR C677T variant and migraine with aura in an older population: could selective survival play a role? Cephalalgia 33(5): $308-15$.

56. Essmeister R, Kress HG, Zierz S, Griffith L, Lea R, Wieser T (2016) MTHFR and ACE Polymorphisms Do Not Increase Susceptibility to Migraine Neither Alone Nor in Combination. Headache 56(8): 1267-73.

57. Kaur S, Ali A, Pandey AK, Singh B (2018) Association of MTHFR gene polymorphisms with migraine in North Indian population. Neurological Sciences, doi.org/10.1007/s10072-018-3276-7.

58. Salehi M, Amin-Beidokhti M, Safarpour Lima B, Gholami M, Javadi GR, Mirfakhraie R (2018) The rs4846049 polymorphism in the 3'UTR region of the MTHFR gene increases the migraine susceptibility in an Iranian population. $\mathbf{J}$ Pain Res 11:145-149.

59. Zintzaras E, Sakelaridis N (2007) Is 472G/A catechol-O-methyl-transferase gene polymorphism related to panic disorder? Psychiatr Genet 17(5): 267-73.

60. Tietjen GE (2007) Migraine as a systemic disorder. Neurology 68: 1555-1556.

61. Vanmolkot FH, Van Bortel LM, de Hoon JN (2007) Altered arterial function in migraine of recent onset. Neurology 68: 1563-1570.

62. Buemi M, Marino D, Di Pasquale G, Floccari F, Ruello A, Aloisi C, Corica F, Senatore M, Romeo A, Frisina N (2001) Effects of homocysteine on proliferation, necrosis, and apoptosis of vascular smooth muscle cells in culture and influence of folic acid. Thromb Res 104(3): 207-13. 
63. Kruman II, Kumaravel TS, Lohani A, Pedersen WA, Cutler RG, Kruman Y, Haughey N, Lee J, Evans M, Mattson MP (2002) Folic acid deficiency and homocysteine impair DNA repair in hippocampal neurons and sensitize them to amyloid toxicity in experimental models of Alzheimer's disease. J Neurosci 22(5):1752-62.

64. Parsons AA, Strijbos PJ(2003) The neuronal versus vascular hypothesis of migraine and cortical spreading depression. Curr Opin Pharmacol 3(1):73-7.

65. Zieminska E, Lazarewicz JW (2006) Excitotoxic neuronal injury in chronic homocysteine neurotoxicity studied in vitro: the role of NMDA and group I metabotropic glutamate receptors. Acta Neurobiol Exp (Wars) 66(4): 301-9.

66. Tzourio C, El Amrani M, Poirier O, Nicaud V, Bousser MG, Alperovitch A (2001) Association between migraine and endothelin type A receptor (ETA-231 A/G) gene polymorphism. Neurology 22(56(10): 1273-7.

67. Rai V, Yadva U, Kumar P (2017) Null association of maternal MTHFR A1298C polymorphism with Down syndrome pregnancy: An updated meta-analysis. The Egyptian J Med Hum Genet 18(1): 9-18.

68. Rai V, Kumar P (2018) Fetal MTHFR C677T polymorphism confers no susceptibility to Down Syndrome: evidence from meta-analysis. Egyptian J Med Hum Genet 19: 53-58.

69. Kumar P, Yadav U, Rai V (2016) Prevalence of glucose 6-pohsphate dehydrogenase deficiency in India: An updated meta-analysis. Egypt J Med Hum Genet 17: 295-302.

70. Rai V (2017) Strong association of C677T polymorphism of methylenetetrahydrofolate reductase gene with nosyndromic cleft lip/palate (nsCL/P). Ind J Clin Biochem 33(1):5-15.

71. Yadav U, Kumar P, Yadav SK, Mishra OP, Rai, V (2015) Polymorphisms in folate metabolism genes as maternal risk factor for Neural Tube Defects: an updated meta-analysis. Metab Brain Dis 30: 7-24.

72. Rai V (2016) Methylenetetrahydrofolate reductase C677T polymorphism and recurrent pregnancy loss risk in Asian population: a meta-analysis. Ind J Clin Biochem 31:402-413.

73. Kumar P, Singh G, Rai V (2018) Evaluation of COMT gene rs4680 polymorphism as a risk factor for endometrial cancer. Ind $\mathrm{J}$ Clin Biochem 10.1007/s12291-018-0799-X

74. Rai V, Kumar P (2017) Methylenetetrahydrofolate reductase C677T polymorphism and risk of male infertility in Asian population. Ind $\mathrm{J}$ Clin Biochem 32(3): 253-226.

75. Rai V (2014) Genetic polymorphisms of methylenetetrahydrofolate reductase (MTHFR) gene and susceptibility to depression in Asian population: a systematic meta-analysis. Cell. Mol. Biol. 2014; 60 (3): 29-36.

76. Yadav U, Kumar P, Gupta S, Rai V (2016) Role of MTHFR C677T gene polymorphism in the susceptibility of schizophrenia: An updated meta-analysis. Asian Journal of Psychiatry 20: 41-51.

77. Rai V, Yadav U, Kumar P, Yadav SK, Gupta S (2017) Methylenetetrahydrofolate reductase A1298C genetic variant and risk of schizophrenia: an updated metaanalysis. Indian J Med Res 145(4):437. 
78. Rai V, Kumar P (2018) Methylenetetrahydrofolate reductase C677T polymorphism and susceptibility to epilepsy. Neurological Sciences doi.org/10.1007/s10072-018-3583-z.

79. Rai V (2016) Association of methylenetetrahydrofolate reductase (MTHFR) gene C677T polymorphism with autism: evidence of genetic susceptibility. Metab Brain Dis 31:727-735.

80. Rai V (2016) Folate pathway gene methylenetetrahydrofolate reductase C677T polymorphism and Alzheimer disease risk in Asian population. Indian $\mathrm{J}$ Clin Biochem 31(3): 245-52.

81. Yadav U, Kumar P, Rai V (2016) Role of MTHFR A1298C gene polymorphism in the etiology of prostate cancer:a systematic review and updated meta-analysis. Egyptian Journal Medical Human Genetics 17(2): 141-148.

82. Kumar P, Yadav U, Rai V (2015) Methylenetetrahydrofolate reductase gene C677T polymorphism and breast cancer risk: Evidence for genetic susceptibility. Meta Gene 6 : 72-84.

83. Rai V, Yadav U, Kumar P (2017) Impact of Catechol-O-methyltransferase Val 158Met (rs4680) polymorphism on breast cancer susceptibility in Asian population. Asian Pac J Cancer Prev 18 (5): 1243-1250.

84. Rai V (2016) Evaluation of the MTHFR C677T polymorphism as a risk factor for colorectal cancer in Asian populations. Asian Pac J Cancer Prev 16(18): 80938100.

85. Kumar P, Rai V (2018) MTHFR C677T polymorphism and risk of esophageal cancer: An updated meta-analysis. The Egyptian Journal of Medical Human Genetics 19: 273-284.

86. Yadav U, Kumar P, Rai V (2018) NQO1 gene C609T polymorphism (dbSNP: rs 1800566) and digestive tract cancer risk: A Meta analysis. Nutrition and Cancer 10.1080/01635581.20.

87. Rubino E, Ferrero M, Rainero I, Binello E, Vaula G, Pinessi L (2009) Association of the C677T polymorphism in the MTHFR gene with migraine: A metaAnalysis. Cephalalgia 29(8): 818-825.

88. Liu R, Geng P, Ma M, Yu S, Yang M, He M, Dong Z, Zhang W. MTHFR C677T polymorphism and migraine risk: A meta-analysis. Journal of the Neurological Sciences 336 (2014) 68-73. 
Table 1. Details of MTHFR C677T genotypes in twenty four included studies

\begin{tabular}{|c|c|c|c|c|c|}
\hline Study & Country & Control/Case & $\begin{array}{l}\text { Genotypes in } \\
\text { cases } \\
\text { CC/CT/TT } \\
\end{array}$ & $\begin{array}{l}\text { Genotypes in } \\
\text { controls } \\
\text { CC/CT/TT } \\
\end{array}$ & $\begin{array}{l}\text { HWE } \\
\text { p- } \\
\text { value }\end{array}$ \\
\hline Kowa et al.,2000 & Japan & $261 / 74$ & $18 / 41 / 15$ & $104 / 132 / 25$ & 0.06 \\
\hline Kara et al.,2003 & Turkey & $136 / 93$ & $36 / 49 / 8$ & $69 / 65 / 2$ & 0.002 \\
\hline Lea et al.,2004 & Australia & $269 / 268$ & $104 / 125 / 39$ & $117 / 129 / 23$ & 0.12 \\
\hline Oterino et al.,2004 & Spain & $204 / 230$ & $105 / 98 / 27$ & $84 / 93 / 27$ & 0.87 \\
\hline Oterino et al.,2005 & Italy & $237 / 329$ & $142 / 147 / 40$ & $94 / 114 / 29$ & 0.53 \\
\hline Scher, et al.,2006 & Netherlands & $1212 / 413$ & $181 / 186 / 46$ & $567 / 527 / 118$ & 0.78 \\
\hline Todt et al.,2006 & Germany & $625 / 656$ & $300 / 279 / 77$ & $251 / 300 / 74$ & 0.27 \\
\hline Kaunisto et al.,2006 & Finland & $900 / 898$ & $521 / 332 / 45$ & $522 / 324 / 54$ & 0.69 \\
\hline Botini et al.,2006 & Italy & $66 / 45$ & $16 / 17 / 12 /$ & $24 / 33 / 9$ & 0.65 \\
\hline Pezzini et al.,2007 & Italy & $105 / 206$ & $75 / 90 / 41$ & $41 / 51 / 13$ & 0.21 \\
\hline Schurks et al.,2008 & USA & $20424 / 4577$ & $2070 / 2038 / 469$ & $9173 / 8939 / 2312$ & 0.57 \\
\hline Ferro et al.,2008 & Portugal & $96 / 186$ & 79/91/16 & $35 / 47 / 14$ & 0.78 \\
\hline Joshi et al.,2009 & India & $150 / 150$ & $54 / 78 / 18$ & $60 / 78 / 12$ & 0.05 \\
\hline Oterino et al.,2010 & Spain & $310 / 427$ & $183 / 184 / 60$ & $117 / 147 / 46$ & 0.98 \\
\hline Schurks et al.,2010 & Iceland & $1357 / 252$ & $116 / 114 / 22$ & $612 / 579 / 166$ & 0.11 \\
\hline Samaan et al.,2011 & Canada & $1402 / 447$ & $181 / 204 / 62$ & $625 / 596 / 181$ & 0.05 \\
\hline Ishii et al.,2012 & Japan & $119 / 91$ & $42 / 31 / 18$ & $37 / 61 / 21$ & 0.63 \\
\hline An et al.,2012 & China & $137 / 151$ & $67 / 60 / 24$ & $80 / 46 / 11$ & 0.24 \\
\hline Azimova et al. ,2013 & Russia & $50 / 83$ & $32 / 33 / 18$ & $26 / 20 / 4$ & 0.95 \\
\hline Bahadir et al.,2013 & Turkey & $107 / 150$ & $50 / 59 / 41$ & $96 / 10 / 1$ & 0.22 \\
\hline Scher et al.,2013 & USA & $1357 / 252$ & $116 / 114 / 22$ & $612 / 579 / 166$ & 0.11 \\
\hline $\begin{array}{l}\text { Essmeister } \quad \text { et } \\
\text { al.,2016 }\end{array}$ & Austria & $420 / 244$ & $189 / 215 / 16$ & $114 / 121 / 9$ & 0.000 \\
\hline Kaur et al.,2018 & India & $23 / 100$ & $6 / 14 / 3$ & $51 / 42 / 7$ & 0.67 \\
\hline Salehi et al.,2018 & Iran & $223 / 275$ & $107 / 91 / 25$ & $159 / 101 / 15$ & 0.84 \\
\hline
\end{tabular}

Table 2. Details of MTHFR A1298C genotypes in three included studies

\begin{tabular}{|c|c|c|c|c|c|}
\hline Study & Country & Control/Case & $\begin{array}{l}\text { Genotypes in } \\
\text { cases } \\
\text { AA/AC/CC }\end{array}$ & $\begin{array}{l}\text { Genotypes in } \\
\text { controls } \\
\text { AA/AC/CC }\end{array}$ & $\begin{array}{l}\text { HWE } \\
\text { p- } \\
\text { value }\end{array}$ \\
\hline Kara et al.,2003 & Turkey & $136 / 102$ & $45 / 45 / 12$ & $72 / 62 / 2$ & 0.005 \\
\hline Kaur et al.,2018 & India & $77 / 23$ & $6 / 11 / 6$ & $23 / 30 / 24$ & 0.05 \\
\hline Salehi et al.,2018 & Iran & $275 / 223$ & $81 / 101 / 41$ & $100 / 134 / 41$ & 0.72 \\
\hline
\end{tabular}


Table 3: Summary estimates for the odds ratio (OR) of MTHFR C677T in various allele/genotype contrasts, the significance level ( $\mathrm{p}$ value) of heterogeneity test ( $\mathrm{Q}$ test), and the $\mathrm{I}^{2}$ metric and publication bias p-value (Egger Test).

\begin{tabular}{|c|c|c|c|c|c|}
\hline Genetic Models & $\begin{array}{l}\text { Fixed effect } \\
\text { OR }(95 \% \mathrm{CI}), \mathrm{p}\end{array}$ & $\begin{array}{l}\text { Random effect } \\
\text { OR }(95 \% \text { CI }), p\end{array}$ & $\begin{array}{l}\text { Heterogeneit } \\
\text { y p-value (Q } \\
\text { test) }\end{array}$ & $\mathbf{I}^{2}(\%)$ & $\begin{array}{l}\text { Publicati } \\
\text { on Bias } \\
\text { (p of } \\
\text { Egger's } \\
\text { test) }\end{array}$ \\
\hline Allele Contrast ( $\mathrm{T}$ vs $\mathrm{C}$ ) & $1.00(0.99-1.02), 0.64$ & $1.18(1.00-1.26), 0.05$ & $<0.0001$ & 87.57 & 0.099 \\
\hline Co-dominant (Ct vs CC) & $1.02(0.97-1.07), 0.36$ & $1.08(0.97-1.07), 0.25$ & $<0.0001$ & 70.0 & 0.39 \\
\hline Homozygote (TT vs CC) & $1.20(0.99-1.1), 0.91$ & $1.24(1.0-1.51), 0.04$ & $<0.0001$ & 70.86 & 0.06 \\
\hline Dominant (TT+CT vs CC) & $1.03(0.98-1.08), 0.24$ & $1.15(1.00-1.29), 0.04$ & $<0.0001$ & 81.2 & 0.12 \\
\hline Recessive (TT vs CT+CC) & $1.01(0.64-0.73),<0.0001$ & $1.97(1.28-3.42), 0.002$ & $<0.0001$ & 95.68 & $<0.001$ \\
\hline \multicolumn{6}{|l|}{ Asian studies (study) } \\
\hline Allele Contrast ( $\mathrm{T}$ vs C) & $1.90(1.13-1.58), 0.008$ & $1.91(1.06-3.45), 0.03$ & 0.01 & $67.4 \%$ & 0.78 \\
\hline Co-dominant (Ct vs CC) & $1.55(1.24-1.98),<0.0001$ & $1.47(1.16-1.85) 0.001$ & $<0.0001$ & 88.76 & 0.28 \\
\hline Homozygote (TT vs CC) & $2.99(2.13-4.22),<0.001$ & $2.98(1.56-5.68), 0.008$ & $<0.0001$ & 80.79 & 0.054 \\
\hline Dominant (TT+CT vs CC) & $1.84(1.49-2.26),<0.0001$ & $1.96(0.90-4.24), 0.08$ & $<0.0001$ & 91.81 & 0.192 \\
\hline Recessive (TT vs CT+CC) & $2.58(1.86-3.5),<0.0001$ & $2.5(1.33-4.67), 0.004$ & 0.008 & 67.57 & 0.02 \\
\hline \multicolumn{6}{|l|}{ Caucasian studies (study) } \\
\hline Allele Contrast ( $\mathrm{T}$ vs C) & $0.94(0.93-1.01), 0.19$ & $0.97(0.87-1.08), 0.19$ & $<0.0001$ & $90.11 \%$ & 0.02 \\
\hline Co-dominant (Ct vs CC) & $0.99(0.94-1.05), 0.99$ & $0.99(0.95-1.05), 0.99$ & 0.58 & 0 & 0.44 \\
\hline Homozygote (TT vs CC) & $0.94(0.86-1.01), 0.12$ & $0.99(0.86-1.15), 0.95$ & 0.02 & 45.31 & 0.13 \\
\hline Dominant (TT+CT vs CC) & $0.98(0.94-1.03), 0.59$ & $0.98(0.92-1.05), 0.66$ & 0.33 & 10.37 & 0.94 \\
\hline Recessive (TT vs CT+CC) & $0.93(0.86-1.02), 0.12$ & $0.99(0.86-1.15), 0.95$ & 0.02 & 45.31 & 0.14 \\
\hline \multicolumn{6}{|l|}{$\begin{array}{l}\text { Migraine with Aura } \\
\text { (study) }\end{array}$} \\
\hline Allele Contrast ( $\mathrm{T}$ vs $\mathrm{C}$ ) & $1.11(1.03-1.18), 0.003$ & $1.26(1.03-1.54), 0.02$ & $<0.0001$ & 87.09 & 0.09 \\
\hline Co-dominant (Ct vs CC) & $1.03(0.93-1.13), 0.59$ & $1.1(0.87-1.37), 0.40$ & $<0.0001$ & 73.29 & 0.14 \\
\hline Homozygote (TT vs CC) & $1.31(1.12-1.52), 0.0005$ & $1.51(1.05-2.17), 0.02$ & $<0.0001$ & 76.09 & 0.148 \\
\hline Dominant (TT+CT vs CC) & $1.08(0.99-1.18), 0.09$ & $1.21(0.94-1.55), 0.14$ & $<0.0001$ & 82.22 & 0.11 \\
\hline Recessive (TT vs CT+CC) & $1.3(1.13-1.5), 0.0003$ & $1.45(1.06-1.96), 0.02$ & $<0.0001$ & 71.18 & 0.28 \\
\hline \multicolumn{6}{|l|}{$\begin{array}{l}\text { Migraine without aura } \\
\text { (study) }\end{array}$} \\
\hline Allele Contrast ( $\mathrm{T}$ vs $\mathrm{C}$ ) & $0.99(0.91-1.07), 0.80$ & $1.07(0.84-1.36), 0.56$ & $<0.0001$ & 87.5 & 0.22 \\
\hline Co-dominant (Ct vs CC) & $0.99(0.88-1.10), 0.87$ & $1.02(0.78-1.32), 0.88$ & $<0.0001$ & 78.58 & 0.64 \\
\hline Homozygote (TT vs CC) & $0.95(0.80-1.14), 0.62$ & $1.05(0.70-1.56), 0.81$ & $<0.0001$ & 72.89 & 0.17 \\
\hline Dominant (TT+CT vs CC) & $0.99(0.89-1.10), 0.94$ & $1.06(0.78-1.42), 0.7$ & $<0.0001$ & 85.2 & 0.40 \\
\hline Recessive (TT vs CT+CC) & $0.96(81-1.14), 0.69$ & $1.02(0.74-1.41), 0.88$ & 0.0004 & 62.68 & 0.11 \\
\hline
\end{tabular}


Table 4: Summary estimates for the odds ratio (OR) of MTHFR A1298C in various allele/genotype contrasts, the significance level ( $\mathrm{p}$ value) of heterogeneity test ( $\mathrm{Q}$ test), and the $\mathrm{I}^{2}$ metric and publication bias p-value (Egger Test).

\begin{tabular}{|l|l|l|l|l|l|}
\hline Genetic Models & $\begin{array}{l}\text { Fixed effect } \\
\text { OR }(95 \% \text { CI), }\end{array}$ & $\begin{array}{l}\text { Random effect } \\
\text { OR }(\mathbf{9 5 \%} \text { CI), p }\end{array}$ & $\begin{array}{l}\text { Heterogeneity } \\
\text { p-value }(\mathbf{Q} \\
\text { test) }\end{array}$ & $\mathbf{I}^{\mathbf{2}(\%)}$ & $\begin{array}{l}\text { Publication } \\
\text { Bias (p of } \\
\text { Egger's test) }\end{array}$ \\
\hline Allele Contrast (T vs C) & $1.18(0.96-1.44), 0.11$ & $1.2(0.90-1.58) 0.19$ & 0.22 & 33.36 & 0.88 \\
\hline Co-dominant (Ct vs CC) & $1.03(0.76-1.39), 0.84$ & $1.02(0.75-1.39), 0.85$ & 0.69 & 0 & 0.32 \\
\hline Homozygote (TT vs CC) & $1.55(1.0-2.4) 0.05$ & $1.9(0.62-5.98), 0.25$ & 0.03 & 69.97 & 0.57 \\
\hline $\begin{array}{l}\text { Dominant (TT+CT vs } \\
\text { CC) }\end{array}$ & $1.13(0.85-1.51), 0.39$ & $1.13(0.85-1.51), 0.39$ & 0.54 & 0 & 0.68 \\
\hline $\begin{array}{l}\text { Recessive (TT vs } \\
\text { CT+CC) }\end{array}$ & $1.47(0.98-2.19), 0.05$ & $1.7(0.61-4.91), 0.30$ & 0.02 & 71.92 & 0.04 \\
\hline
\end{tabular}




\section{Pubmed, Google Scholar,} Science Direct, Elsevier Link databases searched

126 articles retrieved

Irrelevant articles $=83$ (includes Book Chapters, Case reports, Comments, Editorials, Letter to Editors, Reviews, meta-analysis, and other polymorphism studied)
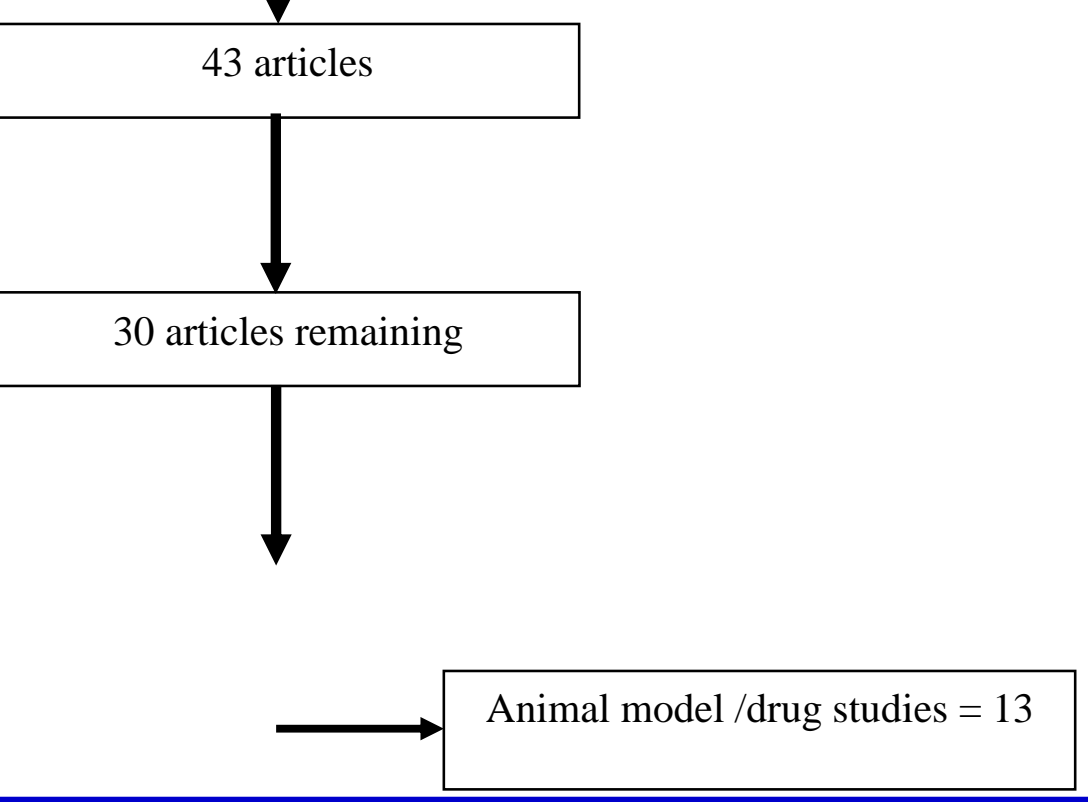

Only cases studies $=1 ;$ Duplicate $=3$;

Insufficient data $=2$

24 articles found suitable for meta-analysis (C677T polymorphism=24 studies) A1298C polymorphism=3 studies 
Figure 1. Flow Diagram of Study Search and Selection Process.

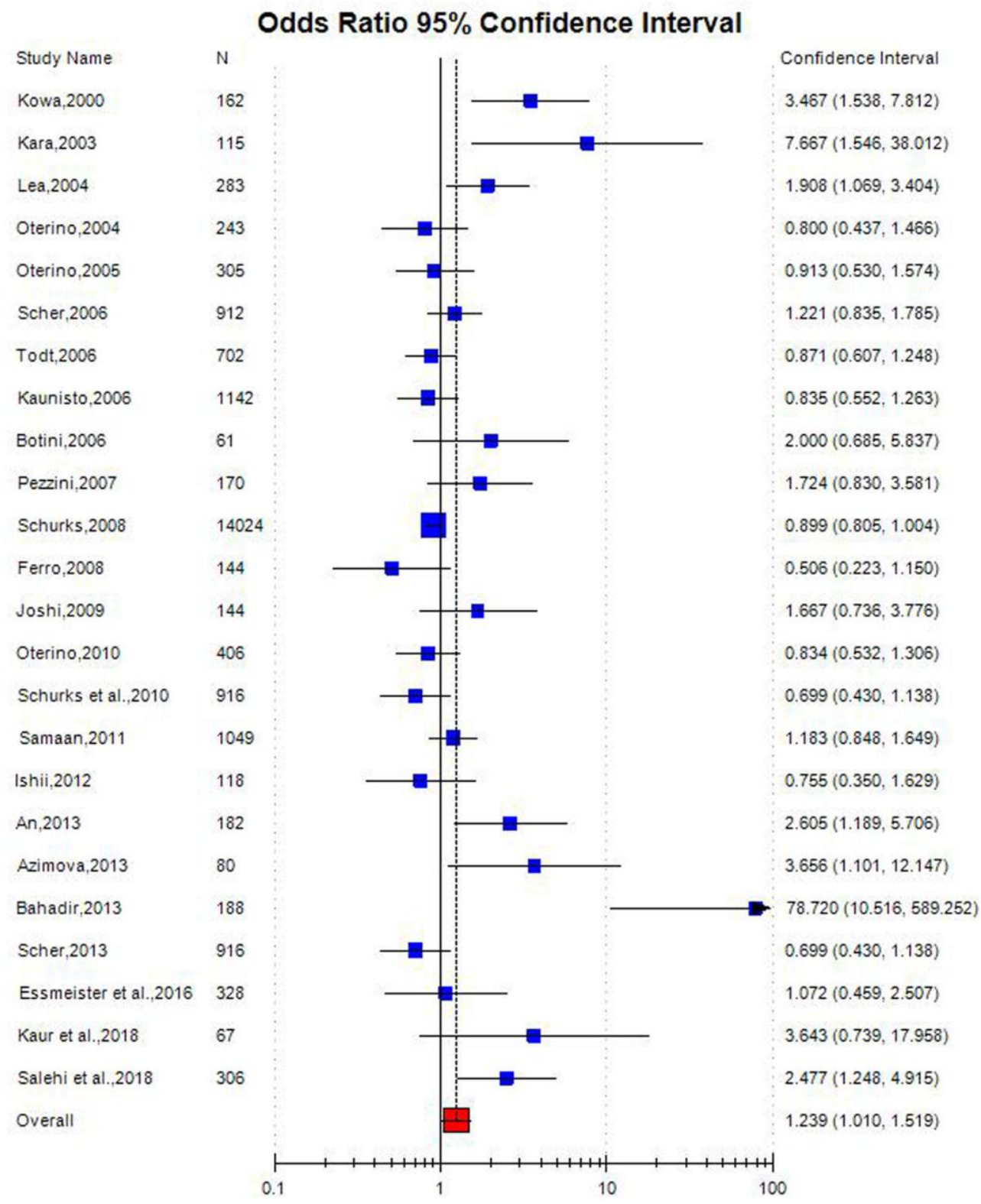

Figure 2. Random effect Forest plot of MTHFR C677T polymorphism of homozygote model (TT vs. CC) of total 24 studies. 


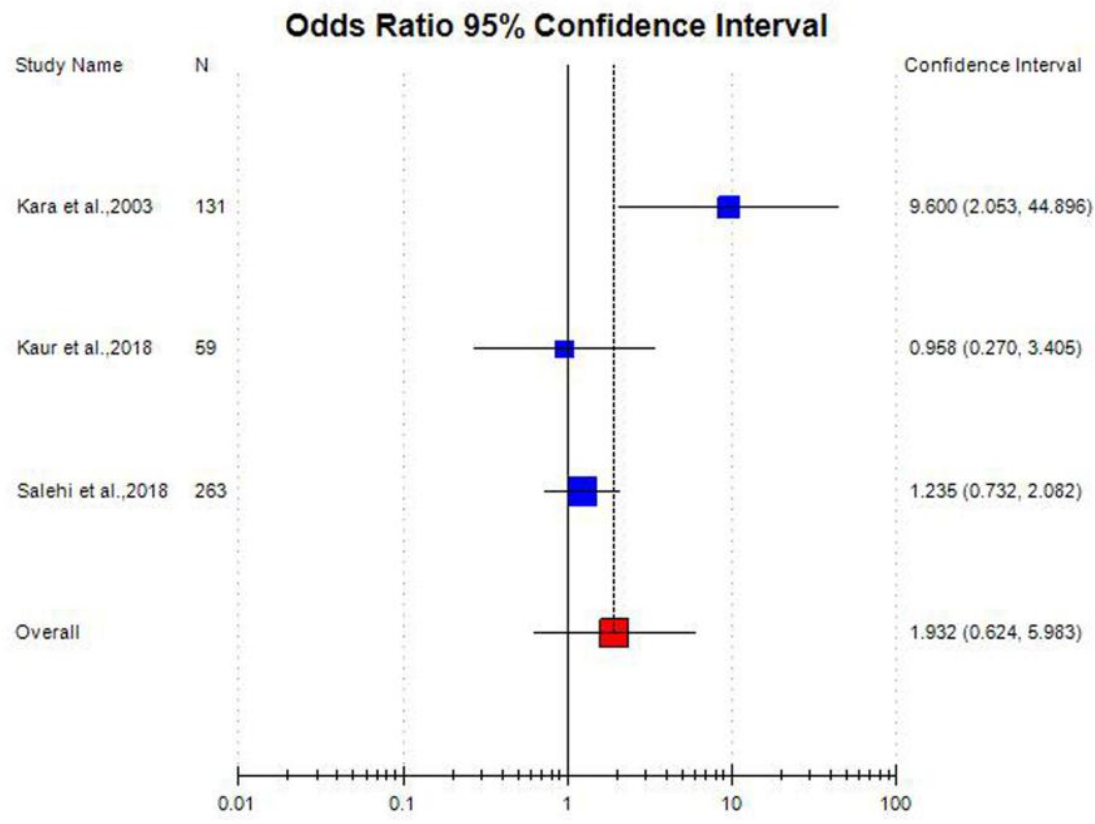

Figure 3. Random effect Forest plot of MTHFR A1298C polymorphism of homozygote model (CC vs. AA) of 3 Asian studies 


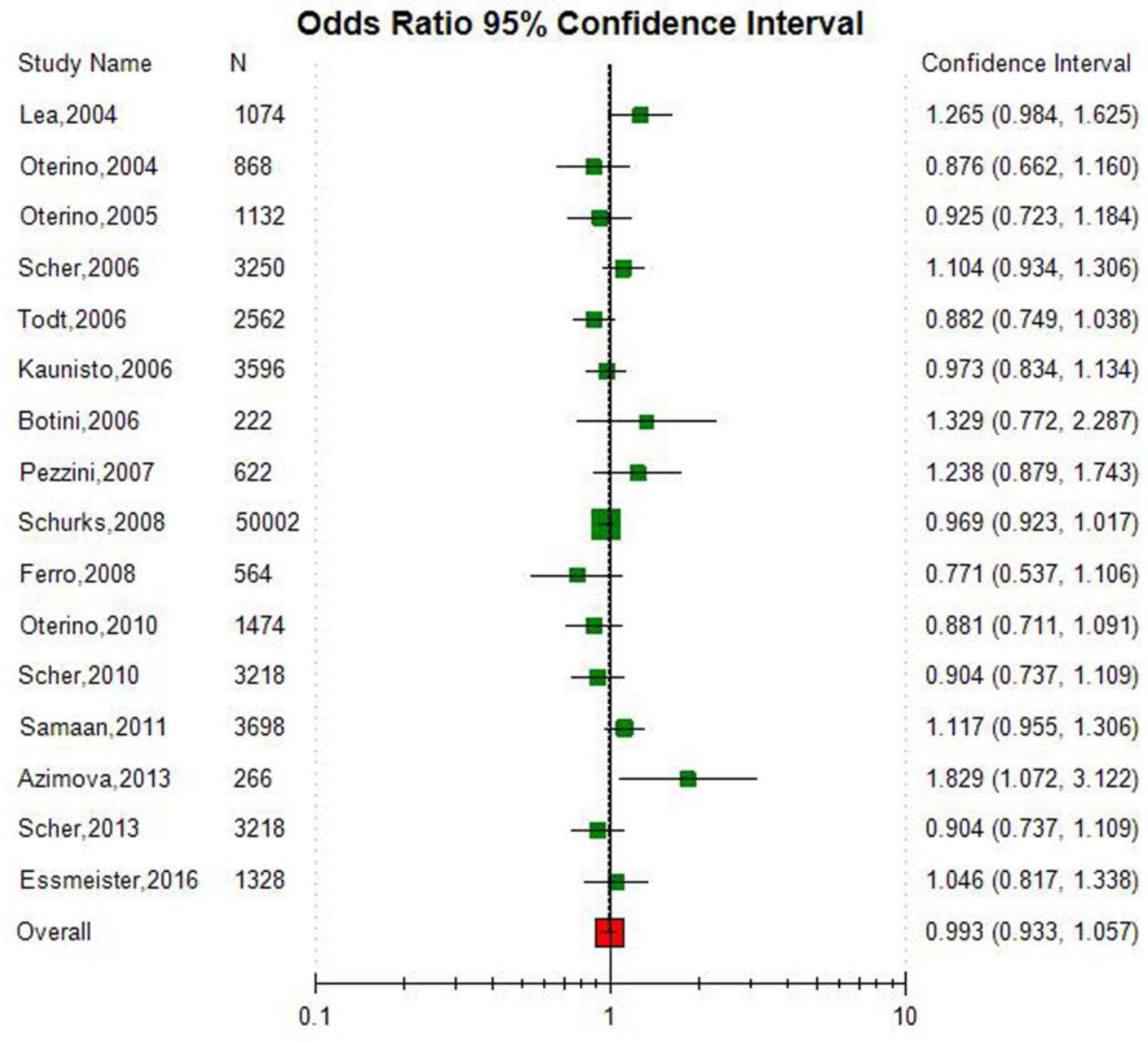

Figure 4. Random effect Forest plot of MTHFR C677T polymorphism of allele contrast model (T vs. C) of 16 Caucasian studies 


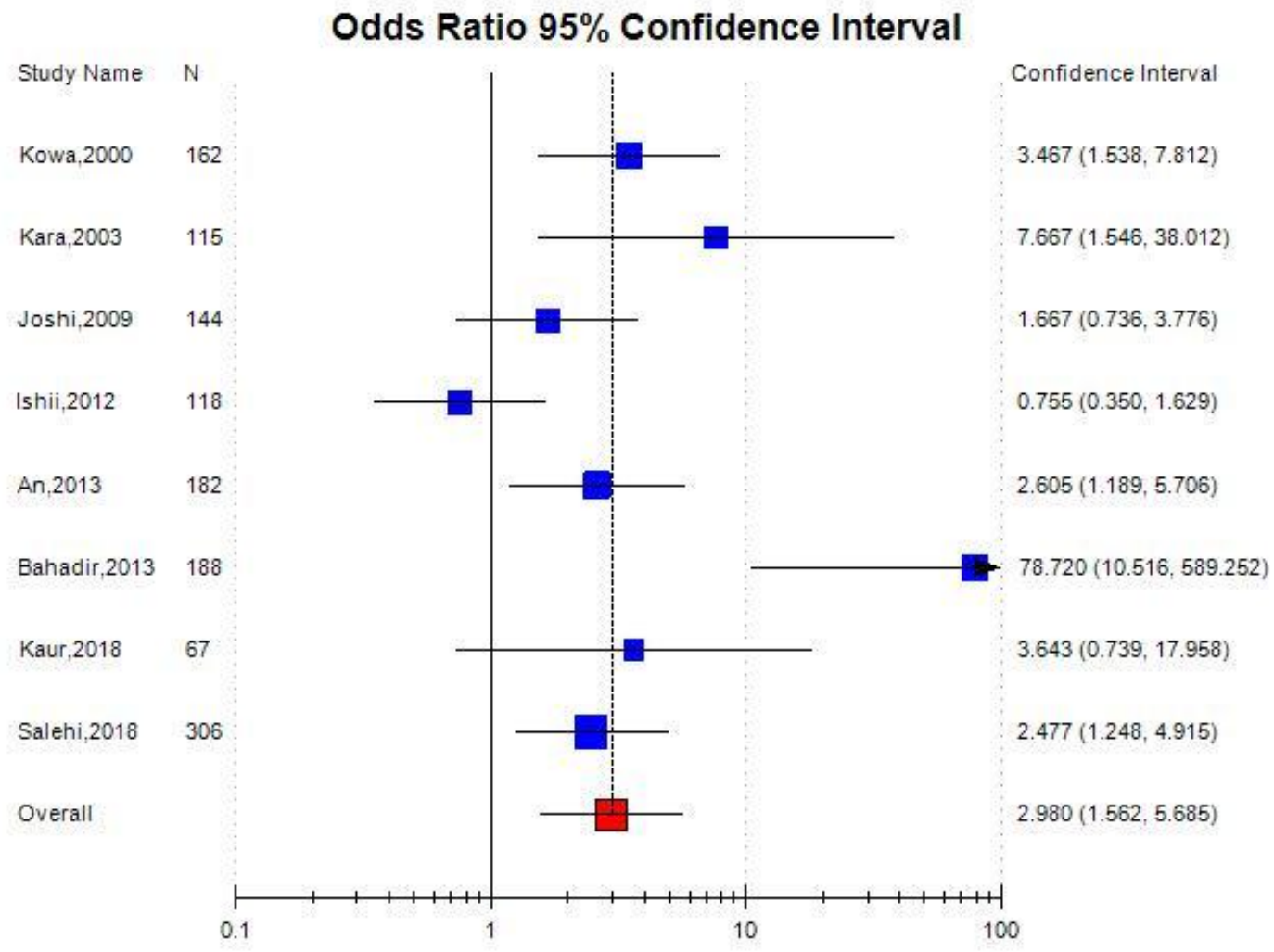

Figure 5. Random effect Forest plot of MTHFR C677T polymorphism of homozygote model (TT vs. CC) of 8 Asian studies 
Study Name

Kowa et al., 2000,MA

Kara et al., 2003,MA

Lea et al., 2004,MA

Oterino et al., 2004,MA

Oterino et al.,2005,MA

Scher et al., 2006,MA

Todt et al., 2006,MA

Kaunisto et al., 2006

Pezzini et al., 2007,MA

Ferro et al.,2008,MA

Joshi et al., 2009,MA

Onterio et al.,2010

Scher et al.,2010 MA

Samaan et al., 2011,MA

Ishii et al.,2012,MA

An et al., 2013,MA

Azimove et al., 2013,MA

Bahadir et al., 2013,MA

Essmeister et al.,2016

Overall

\section{Odds Ratio $95 \%$ Confidence Interval}

N

566

318

874

564

750

2798

2562

3596

410

348

434

1076

3048

3052

286

316

138

370

690

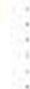

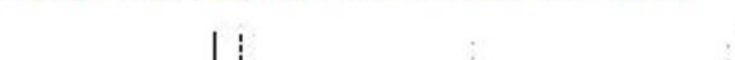

Confidence Interval

$3.269(1.724,6.200)$

$1.038(0.509,2.117)$

$1.411(1.063,1.872)$

$1.235(0.847,1.802)$

$1.199(0.884,1.626)$

$1.363(1.088,1.707)$

$0.882(0.749,1.038)$

$0.973(0.834,1.134)$

$1.501(1.011,2.228)$

$0.652(0.416,1.023)$

$0.361(0.214,0.609)$

$1.040(0.811,1.332)$

$0.846(0.660,1.083)$

$1.369(1.051,1.783)$

$0.936(0.499,1.755)$

$1.358(0.668,2.760)$

$4.408(1.999,9.718)$

$14.805(7.638,28.698)$

$0.987(0.686,1.420)$

$1.261(1.029,1.546)$

Figure 6: Random effect Forest plot of MTHFR C677T polymorphism of allele contrast model (T vs. C) of 19 studies of migraine with aura cases 


\section{Study Name}

Kowa et al., 2000,MO

Kara et al., 2003,MO

Lea et al.,2004,MO

Oterino et al., 2004,MO

Oterino et al., 2005,MO

Scher et al., 2006,MO

Pezzini et al., 2007,MO

Ferro et al.,2008,MO

Joshi et al., 2009,MO

Oterino et al.,2010,MO

Scher et al.,2010,MO

Samaan et al.,2011,MO

Azimove et al., 2012, MO

Ishii et al., 2012,MO

An et al.,2013,MO

Bahadir et al.,2013,MO

Essmeister et al.,2016,MO

Overall

\section{Odds Ratio $95 \%$ Confidence Interval}

N

626

412

738

712

856

2876

422

408

466

1018

2884

3450

228

392

534

358

1126
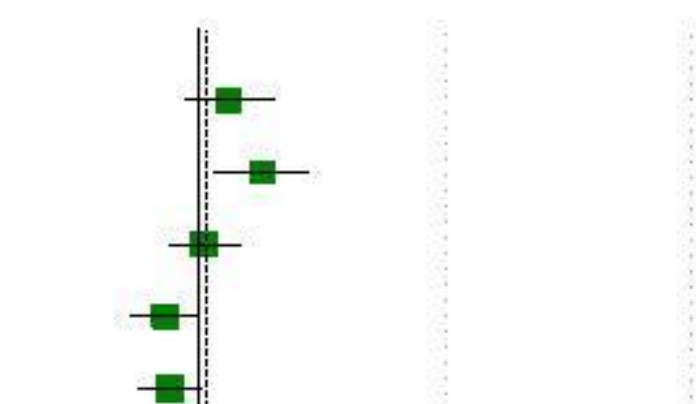

Confidence Interval

$1.317(0.857,2.024)$

$1.792(1.157,2.775)$

$1.045(0.740,1.475)$

$0.723(0.525,0.996)$

$0.756(0.567,1.008)$

$0.917(0.737,1.142)$

$1.026(0.691,1.523)$

$0.864(0.578,1.292)$

$0.344(0.211,0.561)$

$0.721(0.553,0.942)$

$1.025(0.739,1.421)$

$1.030(0.860,1.233)$

$1.394(0.790,2.459)$

$0.593(0.385,0.912)$

$1.744(1.202,2.532)$

$15.061(7.723,29.374)$

$1.065(0.821,1.381)$

$1.070(0.857,1.335)$

Figure 7. Random effect Forest plot of MTHFR C677T polymorphism of allele contrast model (T vs. C) of 17 studies of migraine without aura cases 


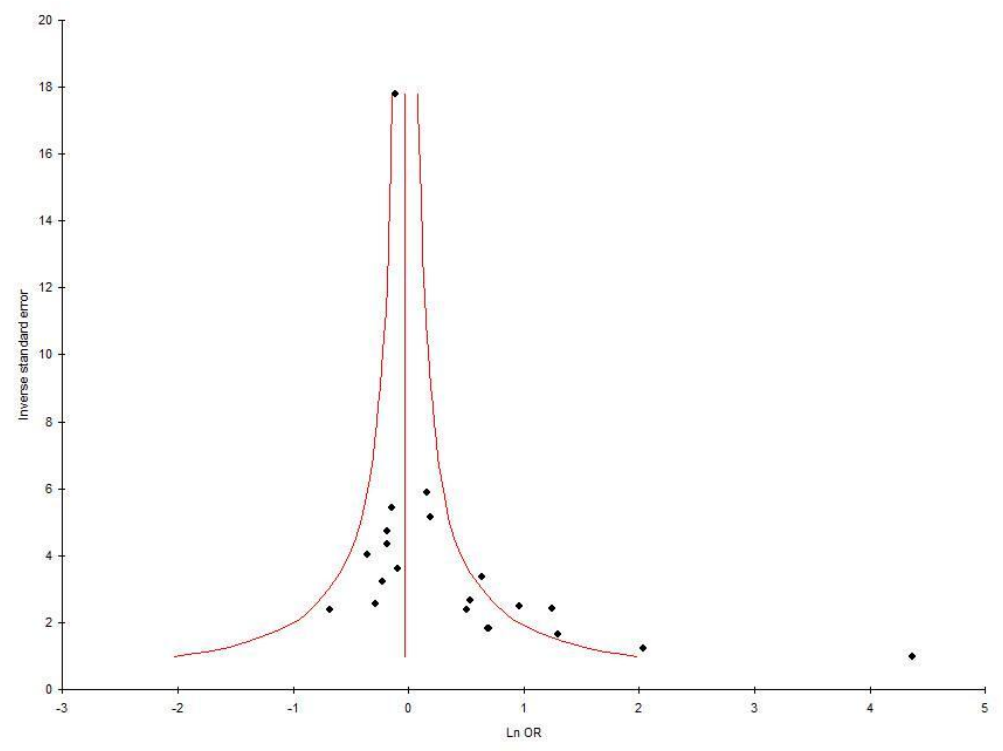

Figure 8.Funnel plot - Precision by log odds ratio for allele contrast model of total 24 studies 